DOI: 10.20472/IAC.2019.050.002

SURATTANA ADIPAT

Faculty of Education, Ramkhamhaeng University, Thailand

\title{
ALONGKORN AUSAWASOWAN
}

Faculty of Education, Ramkhamhaeng University, Thailand

WARANGKANA SEWISET

The Demonstration School of Ramkhamhaeng University, Thailand

RATANAWADEE CHOTIKAPANICH

Faculty of Education, Ramkhamhaeng University, Thailand

\section{TEACHER-CENTERED AND STUDENT-CENTERED PARADIGMS: THINGS TEACHERS NEED TO TAKE INTO SERIOUS CONSIDERATION}

\begin{abstract}
:
Thailand is among a number of ASEAN member countries including Brunei Darussalam, Cambodia, Indonesia, Laos, Malaysia, Myanmar, Philippines, Singapore, and Vietnam. With an agreement among the countries, English is used as an official language for communication. The 11th policy established by the Thai government in 2013 encourages Thai citizens to English to help prepare the country for the ASEAN Economic Community (AEC). The issue of teacher-centered instruction ( $\mathrm{TCl}$ ) and student-centered instruction $(\mathrm{SCl})$ may appear outdated, but it is necessary and should be considered since it can have a major influence on students' language learning. Both instruction types have benefits and drawbacks to varying extents in terms of students' academic success, learning motivation, and maintaining student attention. This study aims to investigate the pre-service teachers' perspectives towards $\mathrm{TCl}$ and $\mathrm{SCl}$. The results yield a significant contribution to the development of English courses which enhance students' knowledge and skills, promote student engagement in the learning process, and enable students to transfer the knowledge they gain in class to their long-term memory. As with any course design and development, properly designed courses that meet students' varying needs are of the utmost importance.
\end{abstract}

\section{Keywords:}

English course, pre-service teachers, student-centered instruction, teacher-centered instruction, perspective

JEL Classification: 129 


\section{Introduction ${ }^{1}$}

The Association of Southeast Asian Nations consists of ten countries: Brunei, Cambodia, Indonesia, Laos, Malaysia, Myanmar, the Philippines, Singapore, Thailand, and Vietnam, which use English as the official language of communication (ASEAN Charter, 2008). According to the Office of the Education Council (2013), the Thai government's $11^{\text {th }}$ policy on education emphasizes encouraging Thai people to speak English to prepare the country for ASEAN Economic Community (AEC). The Royal Thai Government also expected that $80 \%$ of students in Thailand could speak English and be ready to enter the ASEAN community by 2015 . Although Thailand is generally a nonEnglish speaking country, English instruction is beneficial to students since it makes them more employable in other countries (Dearden, 2014). It is therefore mandatory for schools to make great efforts to improve their English language teaching (Fredrickson, 2016).

According to Darasawang (2007), many schools in Thailand employ traditional teaching methods, including monologue instruction or chalk and talk, reading aloud, translating between English and Thai, passive reading or watching videos, and memorizing vocabulary and grammar rules. These methods continue to be commonly used, despite previous studies indicating that integrating other methods of instruction yields improved learning and higher student achievement (Marzano, Pickering, \& Pollock, 2001). Consequently, limited student engagement while learning English negatively affects their attention and focus, their speaking practice motivation, and their expectations of having meaningful learning experiences (Arunsuksawang \& Sungrugsa, 2015). The reform of English language teaching in Thailand has focused on improving communicative language teaching, emphasizing learner-centeredness and communication (Richards, 2006). However, some studies find benefits from teachercentered approaches, such as Ellis (2003) who considered that teacher-centered instruction can maximize students' academic success so long as the teacher can motivate students and maintain their attention in class. Additionally, Tursunov (2016) also argued that teacher-centered instruction should not be prohibited or deemed useless since properly designed lessons can increase students' knowledge and motivation.

\footnotetext{
${ }^{1}$ Authors:

Surattana Adipat, Ph.D.; Assistant Professor, Ramkhamhaeng University, Thailand Alongkorn Ausawasowan; Lecturer, Ramkhamhaeng University, Thailand Ratanawadee Chotikapanich; Associate Professor, Ramkhamhaeng University, Thailand Warangkana Sewiset; Lecturer, The Demonstration School of Ramkhamhaeng University (Secondary), Thailand
} 
Various teaching methods that can be broadly classified into teacher-centered and student-centered methods have been employed in English language teaching, including: the Silent Way (learning English through physical objects and problem-solving skills); Grammar Translation (English directly taught and explained in the learners' native language or through translation); Audio-Lingual (learning English through sentence repetition with a limited use of explicit explanations and the students' native language); Total Physical Response (learning English by listening to verbal commands and physically responding while accepting learners' native language); Natural Approach (learning English through the use of receptive skills); Content-Based Instruction (mastering English while achieving the content objectives); Communicative Language Teaching (achieving communicative competence while emphasizing both fluency and accuracy); Task-Based Language Teaching (using English to accomplish non-linguistic tasks); Problem-Based Learning (employing problem-solving skills through real-life scenarios); Inquiry-Based Learning (seeking knowledge and information through questioning); and Phenomenon-Based Learning (observing and analyzing real-life events through an interdisciplinary approach). The aforementioned methods are supported by numerous studies, and have been shown to improve learners' English skills and knowledge to varying extents. Nonetheless, teachers must investigate their advantages and disadvantages based upon their target learners and school settings to promote meaningful engagement and develop positive attitudes and language development.

The present study examined pre-service teachers' preferences of the teacher-centered and student-centered approaches in the English courses that they were required to enroll in during their five-year teacher preparation program. The findings of this study can facilitate course development to prepare pre-service teachers for their future careers in the $21^{\text {st }}$ century in which English is an important component of success.

\section{Key Concepts of Teacher-Centered and Student-Centered Instruction}

According to Bain (2004), the primary difference between teacher-centered and learnercentered instruction is that "Teaching is something that instructors do to students", while in learner-centered instruction, "Teaching is engaging students, engineering an environment in which they learn" (p.48). Mehan (1979) suggests that the teachercentered approach was influenced by the concept that knowledge must be delivered from teachers to learners. The learning process in traditional, non-interactive classes was adapted from the IRE structure (initiative, response, evaluation). In the teacher-centered English classroom, the teacher's primary responsibilities are to impart knowledge and teach skills to learners, in addition to evaluating and improving the learners' performance in accordance with the criteria set by the teacher. The students' 
role is as a follower who always listens and obtains knowledge from the teacher. Additionally, the teacher is expected to centrally manage the instructional process. Williams (1980) also indicated that the IRE structure means that the teacher is always in front of the class giving lectures and asking students questions so that the students can demonstrate the knowledge they have gained and allowing the teacher to evaluate their responses. The teacher as the center of the classroom is a tradition deeply rooted in the core values of Thai society which places emphasis on respect for elders.

On the contrary, the concept of student-centered learning was derived from constructivist learning theory, which asserts that each individual constructs knowledge uniquely and in multiple ways (Vygotsky, 1978). This is from the experiential model which emphasizes the process of learning through experience (Felicia, 2011); and from the active learning model, which suggests that all learning activities require the student's engagement in doing a particular activity or task, thinking about the things they are doing, and interacting with others (Fink, 2002). In student-centered instruction, learners are at the heart and at the center of the learning process (Lea, Stephenson, \& Troy, 2003; Machemer \& Crawford, 2007). According to Collins and O'Brien (2003), students influence the content, activities, materials, and pace of learning, and they are provided with opportunities to learn independently and maximize their learning from one another. Effective student-centered instruction requires the teacher to employ techniques such as active learning experiences, scenarios requiring critical or creative thinking skills, simulations and role-plays, and self-paced or cooperative learning. These have positive impacts in terms of increased language learning motivation, greater knowledge retention, and more positive attitudes towards the subject.

Collins and O'Brien (2003) suggest that student-centered instruction should:

1. Focus on interactive learning that involves hands-on, real-world processes of imparting knowledge in classrooms, connecting new knowledge to prior knowledge or bridging old and new information, stimulating interest, providing learners with opportunities to choose, control, and adjust based on each individual's different needs and personalities, providing care, and creating an atmosphere that promotes learning.

2. Develop knowledge and skills through authentic contexts geared towards the world in which the learner lives and connect in-school learning experiences with realworld settings.

3. Provide learners with opportunities to take ownership of the learning process rather than taking the role of knowledge recipients. Learners participate and feel a sense of responsibility as they consider their own learning goals, get a clear life direction, and seek out learning resources.

4. Organize a variety of classroom activities and projects to help learners experience using their unnoticed abilities and increase the teacher's awareness of their 
students' different abilities, proficiencies, passions, learning styles, and learning strategies.

5. Create a positive learning atmosphere that promotes learner participation and autonomy in learning, both inside and outside the classroom.

6. Place more emphasis on intrinsic motivation than extrinsic motivation. For instance, a learner may submit their work because they want to feel proud of their ability and effort, rather than for the purpose of receiving praise or compliments from others.

In the $21^{\text {st }}$ century classroom, teachers are encouraged to employ student-centered instruction that focuses on active learning and student engagement. Dewey's (1963) experiential learning_or the learning by doing concept-plays an important role in classroom instruction. The learner's role has changed from a receiver or follower to a learner or performer, while the teacher's role has changed from an instructor to a task setter and facilitator to provide students with opportunities to explore and apply their knowledge in practical endeavors. The learner is therefore now at the center of instruction, with the focus on learning through doing. Furthermore, since teachers generally have to cover large amounts of information within the limitations of short class time, the students absorb information in class, commit it to memory in the short term, and then forget it. In order for information to be transferred to long-term memory, the learner must practice and utilize the content as much as possible.

In light of growing evidence concerning the effectiveness of the student-centered learning approach, Fouts and Myer (1992) contended that students' participation in complex, student-centered activities promotes meaningful student engagement, leading to more positive student attitudes and language development. Thompson (1991) claims that the use of student-centered instruction and authentic materials for pre-literate adult learners enhances literacy skills due to the fact that student-centered classrooms allow for the creation of a learning environment that the students consider more comfortable. Handelsman et al. (2004) maintained that instead of only providing lectures, lectures should be supplemented with active learning strategies, while increasing student engagement in the learning process improves learning and knowledge retention.

In response to the literature review on teacher-centered and student-centered approaches, this study examined pre-service teachers' expectations for the English courses in which they are required to enroll during their study. The findings of the present study can facilitate the development of the course and shed light on future research.

\section{Methodology}

A questionnaire was used, containing a set of closed-ended questions to gain quantitative insights, and open-ended questions for additional concerns or opinions. The 
five-point Likert-scale was employed to measure the participants' attitudes using a fixed response choice format. The participants were required to respond with the extent to which they either agreed or disagreed with each statement on the questionnaire, with each response having a numerical value from 1 (strongly disagree) to 5 (strongly agree).

While developing the questionnaire, the questionnaire was drafted and then reviewed by three experienced faculty members with expertise in English teaching or course design. Ambiguous questions that could potentially yield questionable data were removed, and certain items were revised upon the reviewers' suggestion. After making the revisions, the questionnaire was subsequently sent back to the experts along with an Item-Objective Congruence Index (IOC) form on which they were required to select the degree of content validity (yes, not sure, or no) to verify the questionnaire's validity and ensure that it assessed what it was supposed to assess. The IOC value of each questionnaire item was higher than 0.5 .

The Google Forms questionnaire consisted of three main sections: the participants' general information (age, grade level, and English proficiency level), statements about student-centered and teacher-centered approaches, and additional suggestions. The questionnaire was distributed to 245 students studying at the Curriculum and Instruction Department, Faculty of Education, Ramkhamhaeng University due to accessibility to these students. One-hundred and twenty-five questionnaires were returned, corresponding to a $51 \%$ response rate. Additionally, 13 of the returned questionnaires appeared incomplete and were subsequently excluded, leaving 112 usable questionnaire responses for data analysis.

The questionnaire data were analyzed using descriptive statistics in the form of mean and standard deviation, and inferential statistics, the One-Way ANOVA, which tests whether two or more groups significantly differ from each other.

\section{Findings}

The findings section begins by presenting the demographic data of the pre-service teachers in the study, including their gender, age, year of study, and level of English proficiency. The second section reports their preference for either teacher-centered or student-centered approaches. Lastly, the questionnaire and finding section ends with an additional comment section, allowing the respondents to provide their opinion on any aspect not captured by the statements in the second section.

\section{Demographics}

Of the 112 respondents, over $96 \%$ were female, $80 \%$ were aged between 18 and 24 years old, and $50 \%$ reported being in their second year of university studies. The 
participants were on nine different major routes during the pre-service program, including 46\% majoring in English Language, $11.60 \%$ in Thai Language, $1.80 \%$ in Arts, $3.60 \%$ in Chinese Language, 1.80\% in Science Education, 5.40\% in Mathematics, 8.0\% in Elementary Education, 10.70\% in Early Childhood Education, and 11.60 in Social Studies. The respondents' English proficiency level was self-rated as "poor" by $53.57 \%$ (listening), 62.5\% (speaking), 35.71\% (reading), and 59.82\% (writing).

2. Participants' Perspectives Towards Teacher-Centered and Student-Centered Instruction The data are categorized into teacher-centered instruction and student-centered instruction. 
Table 1. The Frequency Distribution and Percentage of Perspectives Towards TeacherCentered and Student-Centered Instruction

\begin{tabular}{|c|c|c|c|c|c|}
\hline \multirow[b]{2}{*}{ Statement } & \multicolumn{5}{|c|}{ Frequency $(\%) \quad \mathrm{n}=112$} \\
\hline & $\begin{array}{c}\text { Strongly } \\
\text { Disagree } \\
\text { (1) }\end{array}$ & $\begin{array}{l}\text { Disagree } \\
\quad(2)\end{array}$ & $\begin{array}{c}\text { Neither } \\
\text { Agree nor } \\
\text { Disagree } \\
\text { (3) }\end{array}$ & $\begin{array}{l}\text { Agree } \\
(4)\end{array}$ & $\begin{array}{c}\text { Strongly } \\
\text { Agree } \\
\text { (5) }\end{array}$ \\
\hline \multicolumn{6}{|l|}{ Teacher-centered instruction } \\
\hline $\begin{array}{l}\text { 1. The teacher is the key person who passes on } \\
\text { knowledge to students and improve their skills. }\end{array}$ & $\begin{array}{c}3 \\
(2.68)\end{array}$ & $\begin{array}{c}44 \\
(39.29)\end{array}$ & $\begin{array}{c}12 \\
(10.71)\end{array}$ & $\begin{array}{c}41 \\
(36.61)\end{array}$ & $\begin{array}{c}12 \\
(10.71)\end{array}$ \\
\hline 2. The teacher is the center of knowledge. & $\begin{array}{c}3 \\
(2.68)\end{array}$ & $\begin{array}{c}43 \\
(38.39)\end{array}$ & $\begin{array}{c}12 \\
(10.71)\end{array}$ & $\begin{array}{c}41 \\
(36.61)\end{array}$ & $\begin{array}{c}13 \\
(11.61)\end{array}$ \\
\hline $\begin{array}{l}\text { 3. The teacher manages and directs all classroom } \\
\text { activities. }\end{array}$ & $\begin{array}{c}4 \\
(3.57)\end{array}$ & $\begin{array}{c}43 \\
(38.39)\end{array}$ & $\begin{array}{c}11 \\
(9.82)\end{array}$ & $\begin{array}{c}47 \\
(41.96)\end{array}$ & $\begin{array}{c}7 \\
(6.25)\end{array}$ \\
\hline $\begin{array}{l}\text { 4. The teacher talks, and the students exclusively } \\
\text { listen. }\end{array}$ & $\begin{array}{c}10 \\
(8.93)\end{array}$ & $\begin{array}{c}38 \\
(33.93)\end{array}$ & $\begin{array}{c}13 \\
(11.61)\end{array}$ & $\begin{array}{c}38 \\
(33.93)\end{array}$ & $\begin{array}{c}13 \\
(11.61)\end{array}$ \\
\hline $\begin{array}{l}\text { 5. Students follow the teacher's instructions, and } \\
\text { usually complete the individual seatwork. }\end{array}$ & $\begin{array}{c}5 \\
(4.46)\end{array}$ & $\begin{array}{c}42 \\
(37.50)\end{array}$ & $\begin{array}{c}10 \\
(8.93)\end{array}$ & $\begin{array}{c}43 \\
(38.39)\end{array}$ & $\begin{array}{c}12 \\
(10.71)\end{array}$ \\
\hline $\begin{array}{l}\text { 6. The emphasis is on language forms and } \\
\text { structures taught and explained by the teacher. }\end{array}$ & $\begin{array}{c}18 \\
(16.07)\end{array}$ & $\begin{array}{c}26 \\
(23.21)\end{array}$ & $\begin{array}{c}14 \\
(12.50)\end{array}$ & $\begin{array}{c}35 \\
(31.25)\end{array}$ & $\begin{array}{c}19 \\
(16.96)\end{array}$ \\
\hline $\begin{array}{l}\text { 7. The teacher monitors and corrects students' } \\
\text { utterance. }\end{array}$ & $\begin{array}{c}3 \\
(2.68)\end{array}$ & $\begin{array}{c}44 \\
(39.29)\end{array}$ & $\begin{array}{c}11 \\
(9.82)\end{array}$ & $\begin{array}{c}39 \\
(34.82)\end{array}$ & $\begin{array}{c}15 \\
(13.39)\end{array}$ \\
\hline 8. Classroom remains controlled and orderly. & $\begin{array}{c}5 \\
(4.46)\end{array}$ & $\begin{array}{c}42 \\
(37.50)\end{array}$ & $\begin{array}{c}10 \\
(8.93)\end{array}$ & $\begin{array}{c}43 \\
(38.39)\end{array}$ & $\begin{array}{c}12 \\
(10.71)\end{array}$ \\
\hline 9. Students' classroom discipline is fostered. & $\begin{array}{c}3 \\
(2.68)\end{array}$ & $\begin{array}{c}44 \\
(39.29)\end{array}$ & $\begin{array}{c}10 \\
(8.93)\end{array}$ & $\begin{array}{c}44 \\
(39.29)\end{array}$ & $\begin{array}{c}11 \\
(9.82)\end{array}$ \\
\hline 10. The teacher evaluates students' performance. & $\begin{array}{c}3 \\
(2.68)\end{array}$ & $\begin{array}{c}44 \\
(39.29)\end{array}$ & $\begin{array}{c}10 \\
(8.93)\end{array}$ & $\begin{array}{c}46 \\
(41.07)\end{array}$ & $\begin{array}{c}9 \\
(8.04)\end{array}$ \\
\hline \multicolumn{6}{|l|}{ Student-centered instruction } \\
\hline $\begin{array}{l}\text { 11. Students are encouraged to develop some topic } \\
\text { options for the course. }\end{array}$ & $\begin{array}{c}2 \\
(1.79)\end{array}$ & $\begin{array}{c}37 \\
(33.04)\end{array}$ & $\begin{array}{c}4 \\
(3.57)\end{array}$ & $\begin{array}{c}67 \\
(59.82)\end{array}$ & $\begin{array}{c}2 \\
(1.79)\end{array}$ \\
\hline $\begin{array}{l}\text { 12. Students are allowed to decide on actions they } \\
\text { want to do in class. }\end{array}$ & $\begin{array}{c}2 \\
(1.79)\end{array}$ & $\begin{array}{c}40 \\
(35.71)\end{array}$ & $\begin{array}{c}2 \\
(1.79)\end{array}$ & $\begin{array}{c}65 \\
(58.04)\end{array}$ & $\begin{array}{c}3 \\
(2.68)\end{array}$ \\
\hline 13. Students participate in group discussions. & $\begin{array}{c}4 \\
(3.57)\end{array}$ & $\begin{array}{c}35 \\
(31.25)\end{array}$ & $\begin{array}{c}4 \\
(3.57)\end{array}$ & $\begin{array}{c}66 \\
(58.93)\end{array}$ & $\begin{array}{c}3 \\
(2.68)\end{array}$ \\
\hline $\begin{array}{l}\text { 14. Students are involved in active learning activities } \\
\text { or tasks. }\end{array}$ & $\begin{array}{c}4 \\
(3.57)\end{array}$ & $\begin{array}{c}35 \\
(31.25)\end{array}$ & $\begin{array}{c}7 \\
(6.25)\end{array}$ & $\begin{array}{c}59 \\
(52.68)\end{array}$ & $\begin{array}{c}7 \\
(6.25)\end{array}$ \\
\hline $\begin{array}{l}\text { 15. Students participate in the activities in which } \\
\text { they are encouraged to use English to complete. }\end{array}$ & $\begin{array}{c}3 \\
(2.68)\end{array}$ & $\begin{array}{c}36 \\
(32.14)\end{array}$ & $\begin{array}{c}5 \\
(4.46)\end{array}$ & $\begin{array}{c}65 \\
(58.04)\end{array}$ & $\begin{array}{c}3 \\
(2.68)\end{array}$ \\
\hline $\begin{array}{l}\text { 16. Classroom is often noisy and busy, which } \\
\text { increase students' engagement in learning. }\end{array}$ & $\begin{array}{c}3 \\
(2.68)\end{array}$ & $\begin{array}{c}36 \\
(32.14)\end{array}$ & $\begin{array}{c}7 \\
(6.25)\end{array}$ & $\begin{array}{c}66 \\
(58.93)\end{array}$ & $\begin{array}{c}0 \\
(0.00)\end{array}$ \\
\hline $\begin{array}{l}\text { 17. Students are more responsible for their own } \\
\text { learning. }\end{array}$ & $\begin{array}{c}3 \\
(2.68)\end{array}$ & $\begin{array}{c}36 \\
(32.14)\end{array}$ & $\begin{array}{c}6 \\
(5.36)\end{array}$ & $\begin{array}{c}65 \\
(58.04)\end{array}$ & $\begin{array}{c}2 \\
(1.79)\end{array}$ \\
\hline $\begin{array}{l}\text { 18. Students collaboratively work together in groups } \\
\text { to complete English tasks. }\end{array}$ & $\begin{array}{c}3 \\
(2.68)\end{array}$ & $\begin{array}{c}36 \\
(32.14)\end{array}$ & $\begin{array}{c}4 \\
(3.57)\end{array}$ & $\begin{array}{c}67 \\
(59.82)\end{array}$ & $\begin{array}{c}2 \\
(1.79)\end{array}$ \\
\hline $\begin{array}{l}\text { 19. Students answer each other's questions using } \\
\text { instructor as an information source }\end{array}$ & $\begin{array}{c}2 \\
(1.79)\end{array}$ & $\begin{array}{c}37 \\
(33.04)\end{array}$ & $\begin{array}{c}4 \\
(3.57)\end{array}$ & $\begin{array}{c}67 \\
(59.82)\end{array}$ & $\begin{array}{c}2 \\
(1.79)\end{array}$ \\
\hline $\begin{array}{l}\text { 20. Students evaluate their own learning along with } \\
\text { instructor's evaluations }\end{array}$ & $\begin{array}{c}2 \\
(1.79)\end{array}$ & $\begin{array}{c}37 \\
(33.04)\end{array}$ & $\begin{array}{c}4 \\
(3.57)\end{array}$ & $\begin{array}{c}65 \\
(58.04)\end{array}$ & $\begin{array}{c}4 \\
(3.57)\end{array}$ \\
\hline
\end{tabular}


Among the 112 participants, the results reveal both agreement (31.25\% to $41.96 \%)$ and disagreement $(23.21 \%$ to $39.29 \%)$ with all the teacher-centered statements related to the teacher's role at the center, passing on knowledge, directing all classroom activities, explaining language forms and structure as opposed to engaging students in typical situations, correcting students' utterances, fostering classroom discipline, and evaluating students' performance. Overall, teacher-centered instruction received a mean score of 3.26, indicating a moderate level of agreement.

Over $52 \%$ of the participants agreed with the statements on student-centered instruction. The highest percentage of agreement (59.82\%) was awarded for statements 11,18 and 19, which indicated opportunities for students to develop topic options for the course, working collaboratively with others, and answering each other's questions, respectively. The lowest percentage of agreement (52.68\%) was recorded for statement 14 in relation to student involvement in active learning tasks. Overall, student-centered instruction received a mean score of 3.12 , indicating a moderate level of agreement.

Table 2. One-Way Analysis of Variance Summary Table for Effects of Participants' Perspectives Towards Teacher-Centered Instruction

\begin{tabular}{|c|c|c|c|c|c|c|}
\hline Source & df & SS & MS & $\mathbf{F}$ & $p$ & $\eta^{2}$ \\
\hline Between Groups & 8 & 37.289 & 4.661 & $6.335^{*}$ & .000 & 0.330 \\
\hline Within Groups & 103 & 75.786 & .736 & & & \\
\hline Total & 111 & 113.076 & & & & \\
\hline
\end{tabular}

Table 3. Post hoc Table for Effect of Participants' Perspectives Towards TeacherCentered Instruction

\begin{tabular}{|c|c|c|c|c|c|c|c|c|c|c|c|}
\hline \multirow{2}{*}{ Major } & \multirow{2}{*}{$M$} & \multirow{2}{*}{$S D$} & \multicolumn{9}{|c|}{ Post hoc } \\
\hline & & & (1) & (2) & (3) & (4) & (5) & (6) & (7) & (8) & (9) \\
\hline English & 2.65 & 0.99 & - & & & & & & & & \\
\hline Thai & 3.61 & 0.81 & $\begin{array}{l}-0.95^{*} \\
(.046)\end{array}$ & - & & & & & & & \\
\hline Arts & 4.00 & 0.00 & $\begin{array}{l}-1.35^{*} \\
(.000)\end{array}$ & $\begin{array}{c}-0.39 \\
(.889) \\
\end{array}$ & - & & & & & & \\
\hline Chinese & 4.05 & 0.13 & $\begin{array}{l}-1.40^{*} \\
(.000)\end{array}$ & $\begin{array}{c}-0.44 \\
(.824) \\
\end{array}$ & $\begin{array}{c}-0.05 \\
(1.000)\end{array}$ & - & & & & & \\
\hline Science & 4.10 & 0.14 & $\begin{array}{l}-1.45^{\star} \\
(.001)\end{array}$ & $\begin{array}{l}-0.49 \\
(.758)\end{array}$ & $\begin{array}{l}-0.10 \\
(.973)\end{array}$ & $\begin{array}{c}-0.05 \\
(1.000)\end{array}$ & - & & & & \\
\hline Mathematics & 3.82 & 0.45 & $\begin{array}{l}-1.16^{*} \\
(.008)\end{array}$ & $\begin{array}{c}-0.21 \\
(1.000)\end{array}$ & $\begin{array}{c}0.18 \\
(.998) \\
\end{array}$ & $\begin{array}{c}0.23 \\
(.991) \\
\end{array}$ & $\begin{array}{c}0.28 \\
(.972) \\
\end{array}$ & - & & & \\
\hline Elementary & 3.32 & 1.12 & $\begin{array}{l}-0.67 \\
(.914)\end{array}$ & $\begin{array}{c}0.29 \\
(1.000)\end{array}$ & $\begin{array}{c}0.68 \\
(.847) \\
\end{array}$ & $\begin{array}{c}0.73 \\
(.799) \\
\end{array}$ & $\begin{array}{c}0.78 \\
(.752) \\
\end{array}$ & $\begin{array}{c}0.49 \\
(.997)\end{array}$ & - & & \\
\hline Early Childhood & 4.00 & 0.06 & $\begin{array}{l}-1.35^{*} \\
(.000)\end{array}$ & $\begin{array}{l}-0.39 \\
(.892)\end{array}$ & $\begin{array}{c}0.00 \\
(1.000)\end{array}$ & $\begin{array}{c}0.05 \\
(1.000)\end{array}$ & $\begin{array}{c}0.10 \\
(.976)\end{array}$ & $\begin{array}{l}-0.18 \\
(.998)\end{array}$ & $\begin{array}{c}-0.68 \\
(.848)\end{array}$ & - & \\
\hline Social Studies & 3.78 & 0.81 & $\begin{array}{l}-1.13^{*} \\
(.010) \\
\end{array}$ & $\begin{array}{c}-0.18 \\
(1.000)\end{array}$ & $\begin{array}{c}0.22 \\
(1.000) \\
\end{array}$ & $\begin{array}{c}0.27 \\
(.999) \\
\end{array}$ & $\begin{array}{c}0.32 \\
(.993) \\
\end{array}$ & $\begin{array}{c}0.03 \\
(1.000)\end{array}$ & $\begin{array}{c}-0.46 \\
(1.000)\end{array}$ & $\begin{array}{c}0.22 \\
(1.000)\end{array}$ & - \\
\hline
\end{tabular}

${ }^{\star} \mathrm{p} \leq .05$ The mean difference is significant at the 0.05 level. 
According to Table 2, the One-Way Analysis of Variance (ANOVA) results reveal significant differences among each major $(F[8,103]=6.335, p=.000)$. The difference between each pair obtained by Dunnett's T3 pairwise comparison test (Table 3 ) reveals statistically significant differences $(p<0.05)$ between English major and non-English majors, including Thai, Arts, Chinese, Science, Mathematics, Elementary, Early Childhood, and Social Studies. The mean score of English-major participants' perspectives towards teacher-centered instruction ( $\mathrm{TCl}$ ) was lower than that of the nonEnglish major participants, meaning that the non-English major participants had an overall higher preference for $\mathrm{TCl}$ compared to the English-major participants.

Table 4. One-Way Analysis of Variance Summary Table for Effects of Participants' Perspectives Towards Student-Centered Instruction

\begin{tabular}{lcccccc}
\hline \multicolumn{1}{c}{ Source } & df & SS & MS & $\mathbf{F}$ & $\mathbf{p}$ & $\boldsymbol{\eta}^{\mathbf{2}}$ \\
\hline Between Groups & 8 & 85.883 & 10.735 & $19.263^{*}$ & .000 & 0.600 \\
Within Groups & 103 & 57.402 & .557 & & & \\
Total & 111 & 143.285 & & & & \\
\hline
\end{tabular}

Levene Statistic $=2.894, \mathrm{df}=8,103, \mathrm{p}=.006^{*}$

${ }^{*} p \leq .05$ The mean difference is significant at the 0.05 level.

Table 5. Post hoc Table for Effect of Participants' Perspectives Towards StudentCentered Instruction

\begin{tabular}{|c|c|c|c|c|c|c|c|c|c|c|c|}
\hline \multirow{2}{*}{ Major } & \multirow{2}{*}{$M$} & \multirow{2}{*}{$S D$} & \multicolumn{9}{|c|}{ Post hoc } \\
\hline & & & (1) & (2) & (3) & (4) & $(5)$ & (6) & $(7)$ & $(8)$ & (9) \\
\hline English & 3.94 & 0.79 & - & & & & & & & & \\
\hline Thai & 2.51 & 0.96 & $\begin{array}{l}1.44^{*} \\
(.004)\end{array}$ & - & & & & & & & \\
\hline Arts & 1.95 & 0.07 & $\begin{array}{l}1.99^{*} \\
(.000)\end{array}$ & $\begin{array}{l}0.56 \\
(.725)\end{array}$ & - & & & & & & \\
\hline Chinese & 1.98 & 0.05 & $\begin{array}{l}1.97^{\star} \\
(.000)\end{array}$ & $\begin{array}{c}0.53 \\
(.764)\end{array}$ & $\begin{array}{c}-0.03 \\
(1.000)\end{array}$ & - & & & & & \\
\hline Science & 1.80 & 0.28 & $\begin{array}{l}2.14 \\
(.090)\end{array}$ & $\begin{array}{c}0.71 \\
(.683)\end{array}$ & $\begin{array}{l}0.15 \\
(.997)\end{array}$ & $\begin{array}{l}-0.18 \\
(.988)\end{array}$ & - & & & & \\
\hline Mathematics & 2.25 & 0.77 & $\begin{array}{l}1.69^{*} \\
(.035)\end{array}$ & $\begin{array}{c}0.26 \\
(1.000)\end{array}$ & $\begin{array}{l}-0.30 \\
(.999)\end{array}$ & $\begin{array}{l}-0.45 \\
(.988)\end{array}$ & $\begin{array}{l}0.45 \\
(.988)\end{array}$ & - & & & \\
\hline Elementary & 3.77 & 0.44 & $\begin{array}{c}0.18 \\
(1.000)\end{array}$ & $\begin{array}{l}-1.26^{*} \\
(.019)\end{array}$ & $\begin{array}{c}-1.82^{*} \\
(.000)\end{array}$ & $\begin{array}{l}-1.97 \\
(.070)\end{array}$ & $\begin{array}{l}-1.52 \\
(.058)\end{array}$ & $\begin{array}{r}1.52 \\
(.058)\end{array}$ & - & & \\
\hline Early Childhood & 1.81 & 0.36 & $\begin{array}{l}2.13^{*} \\
(.000)\end{array}$ & $\begin{array}{l}0.70 \\
(.472)\end{array}$ & $\begin{array}{l}0.14 \\
(.995)\end{array}$ & $\begin{array}{c}-0.01 \\
(1.000)\end{array}$ & $\begin{array}{c}0.44 \\
(.976)\end{array}$ & $\begin{array}{l}1.96^{*} \\
(.000)\end{array}$ & $\begin{array}{l}-1.96^{*} \\
(.000)\end{array}$ & - & \\
\hline Social Studies & 2.44 & 0.89 & $\begin{array}{l}1.50^{\star} \\
(.001)\end{array}$ & $\begin{array}{c}0.07 \\
(1.000)\end{array}$ & $\begin{array}{l}-0.49 \\
(.803)\end{array}$ & $\begin{array}{l}-0.64 \\
(.742)\end{array}$ & $\begin{array}{c}-0.19 \\
(1.000)\end{array}$ & $\begin{array}{l}1.33^{*} \\
(.007)\end{array}$ & $\begin{array}{l}-0.63 \\
(.540)\end{array}$ & $\begin{array}{l}.630 \\
(.540)\end{array}$ & - \\
\hline
\end{tabular}

${ }^{*} p \leq .05$ The mean difference is significant at the 0.05 level.

The ANOVA results in Table 4 reveal significant differences among each major ( $F$ $[8,103]=19.263, p=.000)$. The difference between each pair obtained by Dunnett's T3 pairwise comparison test (Table 5), revealed statistically significant differences ( $p<$ 0.05) between English major and non-English majors, including Thai, Arts, Chinese, Science, Mathematics, Elementary, Early Childhood, and Social Studies. The mean 
score for English-major participants' perspectives towards student-centered instruction $(\mathrm{SCl})$ was higher than for the non-English major participants, meaning that the Englishmajor participants had an overall higher preference for $\mathrm{SCl}$ compared to the nonEnglish major participants. When comparing non-English majors, the difference between the Thai majors, Arts majors, and the Elementary major, was statistically significant $(p<0.05)$, with a lower mean score of 2.51 and 1.95 , respectively, when compared with the Elementary major ( $M=3.77)$. In addition, the difference between the Mathematics major and the Early Childhood and Social Studies majors was statistically significant $(p<0.05)$. The mean score of the Mathematics major $(M=2.25)$ was higher than for the Early Childhood major ( $M=1.81)$, but lower than for the Social Studies major $(M=2.44)$. Lastly, the difference between the Elementary major and the Early Childhood major was statistically significant $(p<0.05)$, with a higher mean score of 3.77 . In other words, the English and Elementary major participants had positive perspectives towards $\mathrm{SCl}$, while the others did not prefer $\mathrm{SCl}$ as evidenced by the low mean scores.

\section{Additional Suggestions or Concerns}

Certain comments about teacher-centered instruction were related to teachers' lack or abundance of motivation to teach, resulting in declined student attention during class. Surprisingly, some participants who rated student-centered instruction lower stated that they did not have a negative attitude towards student-centered instruction. Meanwhile, they considered that this type of instruction could help them improve their English skills. However, speaking English in class would definitely cause them frustration, so listening to lectures would be these students' preferable choice. Additionally, they were unsure whether they have had sufficient knowledge and skills to complete the tasks by themselves.

Although they would be given an opportunity to work in groups, they were concerned that they would not improve their English either if their friends were at the same proficiency level, or if there was little cooperation while completing the tasks. With regards to learner autonomy, they pointed out that if they had to take responsibility for their own English learning, they were afraid they might not gain sufficient knowledge for the examination, and subsequently fail the program. So long as they were required to take English classes and pass the respective exam, they were more concerned about what was taught to ensure they could achieve a good grade on the exam. This was at the expense of learning English to improve their communication skills. More importantly, English as a subject was considered the most difficult, and it took them time to learn or acquire the language. Subsequently, pressure would be placed on both the students and the teacher if the teacher is not aware of their language skills or weaknesses. Therefore, the participants suggested that if student-centered instruction was employed, 
the teacher must be very patient, friendly, approachable, and flexible since most nonEnglish major students would require assistance and a lot of guidance from the teacher.

\section{Conclusions}

This paper investigated pre-service teachers' perspectives towards teacher-centered instruction ( $\mathrm{TCl}$ ) and student-centered instruction ( $\mathrm{SCl}$ ), with the aim of developing English courses. The results suggest that there is a great likelihood that $\mathrm{TCl}$ and $\mathrm{SCI}$ will be integrated and employed in English courses in order to meet the needs of students in all majors. The idealistic roles of teachers include communicating the subject matter, providing demonstrations, engaging students in the learning process, and allowing the students to adapt their role from follower to learner. The results gained from this study potentially contribute to improved course design and development. Furthermore, the results enable the researcher to conduct further research into selecting teaching methods and designing appropriate instructions or lessons.

\section{References}

Arunsuksawang, T., \& Sungrugsa, N. (2015). The factors that have an effect on ability of English usage following the learning skills in the 21st century of the Mattayom 6 students of schools in the Bangkok secondary educational area office 2 to support the entrance into the ASEAN Economic Community. Veridian E-Journal, Silpakorn University, 8(2), 493-505.

Bain, K. (2004). What the best college teachers do? Cambridge, MA: Harvard University Press.

Collins, J. W., \& O'Brien, N. P. (2003). Greenwood dictionary of education. Westport, CT: Greenwood Press.

Darasawang, P. (2007). English language teaching and education in Thailand: A decade of change. In N. D. Prescott (Eds.), English in Southeast Asia: Varieties, literacies and literatures (pp. 187-204). Cambridge Scholars Publishing.

Dearden, J. (2014). English as a medium of instruction - A growing global phenomenon. London: British Council. Retrieved from http://britishcouncil.org/sites/britishcouncil.uk2/files/e484_emi_-_cover_ option_3_final_web.pdf

Dewey, J. (1963). Experience and education. New York: Macmillan.

Ellis, R. (2003). Task-based language learning and teaching. Oxford: Oxford University Press.

Felicia, P. (2011). Handbook of research on improving learning and motivation through educational games: Multidisciplinary approaches. Hershey, PA: IGI Global.

Fink, L. D. (2002). Active learning. Retrieved from http://www.hcc.hawaii.edu

Fouts, J. T., \& Myers, R. E. (1992). Classroom environments and middle school students' views of science. The Journal of Educational Research, 85(6), 356-361.

Fredrickson, T. (2016). ASEAN community challenges Thai English skills. Bangkok Post. Retrieved from http://www.bangkokpost.com/learning/advanced/813852/asean-community-challenges-thai-englishskills

Handelsman, J., Ebert-May, D., Beichner, R., Bruns, P., Chang, A., DeHaan, R., ... Wood, W. B. (2004). Scientific teaching. Science, New Series, 304, 521-522.

Lea, S. J., Stephenson, D., \& Troy, J. (2003). Higher education students' attitudes to student-centered learning: Beyond 'educational bulimia?' Studies in Higher Education, 28(3), 321-334.

Machemer, P. L., \& Crawford, P. (2007). Student perceptions of active learning in a large crossdisciplinary classroom. Active Learning in Higher Education, 8(1), 9-30. 
Marzano, R., Pickering, D., \& Pollock, J. (2001). Classroom instruction that works: Research based strategies for increasing student achievement. Alexandria, VA: ASCD.

Mehan, H. (1979). Learning lessons. Cambridge, MA: Harvard University Press.

Office of the Education Council. (2013). The educational development. Retrieved from http://www.sesao30.go.th/web1/file_editor/file/2557/PLAN2557/Section2.pdf

Richards, J. C. (2006). Communicative language teaching today. Cambridge: Cambridge University Press.

The ASEAN Charter. (2008). ASEAN Secretariat. Retrieved from http://asean.org/wpcontent/uploads/images/archive/publications/ASEAN-Charter.pdf

Thompson, J. B. (1991). Editor's introduction. In P. Bourdieu (Ed.), Language and Symbolic Power. Cambridge, MA: Harvard University Press.

Tursunov, M. M. (2016). A comparative analysis of teacher-centered and learner-centered classes. International Scientific Journal, 6(3), 65-67.

Vygotsky, L. S. (1978). Mind in society: The development of higher psychological processes. Cambridge, Massachusetts: Harvard University Press.

Williams, D. L. (1980). Thai ways and my ways (Report No. SO 015980). Dekalb, IL: Northern Illinois University, Center for Southeast Asian Studies. 